\title{
Vertical distribution of the root system of linseed (Linum usitatissimum L.) and legumes in pure and mixed sowing
}

\author{
Agnieszka Klimek-Kopyra' ${ }^{1 *}$, Tomasz Głąb², Tadeusz Zając', Agnieszka Stokłosa³, Bogdan Kulig' \\ 1 Department of Crop Production, University of Agriculture in Krakow, Al. Mickiewicza 21, 31-120 Kraków, Poland \\ ${ }_{2}^{2}$ Institute of Machinery Exploitation, Ergonomics and Production Processes, University of Agriculture in Krakow, Balicka 116B, 31-149 Kraków, Poland \\ ${ }^{3}$ Department of Agrotechnology and Agricultural Ecology, University of Agriculture in Krakow, Al. Mickiewicza 21, 31-120 Kraków, Poland
}

\begin{abstract}
Root competition for below-ground resources between edible plants may provide for long-term sustainability of agriculture systems. Intercropping can be more productive than a pure crop due to taking advantage of the morphological differences between species. In pure cropping, all biophysical interactions between plants occur through soil conditions. In intercropping, competition for water and nutrients is of major importance, but if the roots of one species occupy the zone just underneath the roots of the other crop, they can better use the resources of the root zone of the crop. The root system demonstrates a high degree of plasticity in its development in response to local heterogeneity of the soil profile and plant density. This study aimed at determining: $(\boldsymbol{i})$ the morphological characteristics of the root systems of linseed, pea and vetch depending on the method of sowing; (ii) the root distribution in various soil types and at different soil profile depths $(0-15 \mathrm{~cm}, 15-30 \mathrm{~cm})$. Two three-year field experiments were conducted on two soil types in south Poland: soil A - Luvic Phaeozem (s1) and soil B - Eutric Cambisol (s2). These results show that linseed was more aggressive toward both legumes in mixture, but it produced lower yield compared to pure cropping. The environmental stress of plants in mixtures increased the relative weight of roots, which resulted in decreasing the root-shoot ratio (RSR).
\end{abstract}

Keywords: Linum usitatissimum L.; Pisum sativum L.; Vicia sativa L.; plant interaction; competition indices; soil depth; root traits

\section{Introduction}

Numerous studies indicate that two-species mixtures of cereals and legumes produce a higher yield as compared to a sole crop $[1,2]$. It is commonly known that the yield of wheat increases following a good forecrop, i.e. legume [3] or oilseed plants [4]. The introduction of annual legumes, along with cereals, into crop rotation increases the content of nitrogen in soil [5], improves soil physical, chemical and biological properties [6,7], and also improves the utilization of space in the canopy [8]. In mixtures with cereals, pea is considered to be more advantageous for wheat than mustard, due to the lower competition for water and as an additional source of nitrogen [9]. Nevertheless, the diversification of plant production in agricultural farms by introducing alternative crop species still requires more studies.

The mixture of linseed and pea provides greater utilization of the yielding potential of plants $[10,11]$ due to more effective water uptake from the deeper soil layers, which enables

\footnotetext{
*Corresponding author. Email: klimek.a@wp.pl
}

Handling Editor: Elżbieta Weryszko-Chmielewska free use of water for subsequent plants [12]. Broadening the knowledge on the development of the root system of alternative plants, such as legumes or oilseed species, can help farmers apply more suitable crop rotation systems and, as a result, to improve the economic viability of farms [13]. Farmers who introduce legumes into the crop rotation increase the yield effectiveness bidirectionally. Firstly, due to the lower pre-sowing doses of nitrogen fertilization, and secondly, due to the increased amounts of nitrogen remaining in the soil after harvest [9].

It is believed that the absorption of nutrients by nonleguminous plants depends on the morphological characteristics of their roots. This leads to the assumption that the supply of nutrients, or the relationship between root length and soil environment, may be the essential components of the root system efficiency. Moreover, a well-developed root system may protect plants from lodging [14]. During drought conditions, the maximum root length and diameter or the shoot to root ratio are considered to be the most important morphological traits [15]. Root length and the number of root branches may also influence the plant's resistance to drought [16]. 
In taking care of agricultural system stability, which results in a significant increase in biodiversity, the positive role of mixed sowing is stressed more and more frequently. The amount volume of studies concerning this subject covers mixed sowing of cereals and cereal-leguminous mixtures. Studies on roots of oilseed plants or legumes are less popular as these plants are considered to be species accompanying cereals. For this reason, studying the development of roots in mixtures of linseed with pea or vetch may be considered to be another learning phase of how the diverse canopy functions in sustainable agriculture. We have claimed that the root morphology demonstrates a high level of plasticity in response to soil heterogeneity and sowing methods. The root system of linseed is adapted to changes in soil environment better than that of legumes. The aim of our research was to determine the morphological characteristics and competition indices of the root systems of three species: linseed (Linum usitatissimum L.), pea (Pisum sativum L.) and vetch (Vicia sativa L.), grown in two different locations and depending on the method of sowing - pure sowing or in pulse-linseed mixture. The second aim was to determine the distribution of their roots in the plough layer of two different types of soil.

\section{Material and methods}

The three-year field experiments were carried out at the Agricultural Experimental Station of the Agricultural University in Prusy, near Kraków $\left(50^{\circ} 07^{\prime} 01^{\prime \prime} \mathrm{N}\right.$ and $20^{\circ} 05^{\prime} 19^{\prime \prime} \mathrm{E}$, $270 \mathrm{~m}$ a.s.l.) and in Olszanica $\left(50^{\circ} 06^{\prime} 01^{\prime \prime} \mathrm{N}\right.$ and $19^{\circ} 58^{\prime} 19^{\prime \prime} \mathrm{E}$, $150 \mathrm{~m}$ a.s.1.) in 2006-2008. The experiment in Prusy was established on Luvic Phaeozem - (s1), whereas in Olszanica on Eutric Cambisol - (s2), according to the WRB classification (WRB 2006). Both types of soil ensure a good habitat for the plants analyzed. Luvic Phaeozem (s1) was fine-grained with the ratio of sand:silt:clay of 14:39:47 and with higher amounts of nutrients $-26.2 \mathrm{mg} 100 \mathrm{~g}^{-1} \mathrm{P}, 16.9 \mathrm{mg} 100 \mathrm{~g}^{-1} \mathrm{~K}$, $13.8 \mathrm{mg} 100 \mathrm{~g}^{-1}$. Eutric Cambisol (s2) was fine-grained with the ratio of sand:silt:clay of 10:77:13 and characterized by a


$100 \mathrm{~g}^{-1} \mathrm{~K}, 11.8 \mathrm{mg} 100 \mathrm{~g}^{-1}$.

In each of the locations ( $\mathrm{s} 1$ and s2), the experiment was set up as a one factorial block design with four replications. The size of each plot was $10 \mathrm{~m}^{2}$. Pea (Pisum sativum L. cv. 'Ramrod'), common vetch (Vicia sativa L. cv. 'Ina') and linseed (Linum usitatissimum L. cv. 'Flanders') were grown in pure sowing or in mixtures. There were three sole crops: L (linseed), P (peas) and vetch (V), and two mixtures: LP (linseed with peas) and LV (linseed with vetch). For both mixtures, the replacement design was used, which involved a 50:50\% replacement of one species with another. The number of seeds sown in pure crops was $480 \mathrm{pcs} \mathrm{m}^{-2}, 80 \mathrm{pcs} \mathrm{m}^{-2}$ and $200 \mathrm{pcs} \mathrm{m}^{-2}$ for linseed, pea and vetch, respectively. In the mixtures, the number of seeds of each species was halved. The crops were fertilized with $48 \mathrm{~kg} \mathrm{ha}^{-1}$ of $\mathrm{P}$ and $72 \mathrm{~kg} \mathrm{ha}^{-1}$ of $\mathrm{K}$ in both years. The total amount of nitrogen fertilization for pure crops and mixtures was as follows: $30 \mathrm{~kg} \mathrm{~N}$ in pure sowing of linseed, $20 \mathrm{~kg} \mathrm{~N}$ in pure sowing of pea, and $40 \mathrm{~kg}$ $\mathrm{N}$ for mixtures. Additionally, nitrogen was used again at the stem extension stage for linseed grown in a pure stand
(20 kg ha $\left.{ }^{-1} \mathrm{~N}\right)$. Weeds, pests and diseases were controlled using appropriate pesticides.

Roots of five plants were sampled at the flowering stage (BBCH 67) using the soil core method. The samples were taken from a $30 \mathrm{~cm}$ depth divided into 2 sections: $0-15 \mathrm{~cm}$ and $15-30 \mathrm{~cm}$. The roots were washed out using a hydropneumatic elutriation system to remove mineral particles. Before scanning, all organic contaminants were manually removed. Digital images were obtained with an Epson Perfection 4870 Photo scanner. The collected images were saved in the .tiff format with a resolution of $600 \mathrm{dpi}$. Then, the images were analyzed using APHELION software and the following root indices were calculated: RLD (root length density) and MRD (mean root diameter). After scanning, the roots were dried at $70^{\circ} \mathrm{C}$ and the root dry weight (RDW) was determined. The root shoot ratio (RSR) was calculated by dividing the total biomass (shoot and root biomass) by the root biomass in the $0-30 \mathrm{~cm}$ layer.

Selected root competition indices for the mixtures of linseed and legumes were calculated, namely relative neighbor effect (RNE), aggressivity $\left(A_{\mathrm{g}}\right)$, and crowding coefficient $(K)$. The effect of the species in the mixture on the production of biomass was assessed through the RNE [17], according to the following formula: $R N E=(X t-X c) / x$, where $X$ refers to the population of target variables in the absence $(t)$ or presence (c) of neighbor species and $x$ is equal to $X t$ when $X t>X c$ or $x=X c$. A competitive relationship between two species in the mixture determines the aggressivity index $(A)$ [18]. Aggressivity is formulated as below: $A_{\text {linseed }}=\{Y w v /(Y w Z w v)\}$ $-\{Y v w /(Y v Z v w)\} ; A_{\text {legume }}=\{Y v w /(Y v Z v w)\}-\{Y w v /(Y w Z w v)\}$, where $Z v w$ and $Z w v$ are the seed rates of common vetch or pea and linseed in the mixture. $A_{\text {linseed }}=0$ refers to the equal competition abilities of two species; if $A_{\text {linseed }}$ has a positive value, it means that linseed is dominant, and if $A_{\text {linseed }}$ has a negative value, then the linseed is dominated by vetch or pea in the mixture [19]. The relative crowding coefficient $(K)$ is a measure of the relative dominance of one species over the other in a mixture [20]. The relative crowding coefficient is calculated as following: $K a b=Y a b Z b a /((Y a a-Y a b) Z a b$; $K b a=Y b a Z a b /((Y b b-Y b a) Z b a)$; where $K a b$ - the relative crowding coefficient for species $a$ in mixture with species $b ; K b a$ - the relative crowding coefficient for species $b$ in mixture with species $a$; Yaa - yield of species $a$ in monoculture; $Y a b$ - yield of species $a$ in mixture with species $b$; $Y b b$ - yield of species $b$ in monoculture; $Y b a$ - yield of species $b$ in mixture with species $a$; $Z a b(\%)$ - ratio of species $a$ to species $b$ in mixture; $Z b a(\%)$ - ratio of species $b$ to species $a$ in mixture.

To evaluate the impact of soil type on the root characteristics, analysis of variance was performed for each soil separately using STATISTICA 10.0 software [21]. Means were separated using Duncan's test at a level of significance of $P \leq 0.05$.

During the growing season (April to August), plants received $294 \mathrm{~mm}$ of water in Prusy (s1) and $289 \mathrm{~mm}$ in Olszanica (s2; average rainfall for 2006-2008; Fig. 1). In Prusy (Luvic Phaeozem - s1) a severe drought was observed in July 2006, in April 2007, and in June 2008. In Prusy (s1) a drought occurred in May, June and July 2008. A severe drought in Olszanica (Eutric Cambisol - s2) was recorded only in July 
s1





Fig. 1 Weather conditions in the regions characterized by different soil types; s1 - Olszanica; s2 - Prusy.

2006 and in June 2008. A drought at this location occurred in April 2007 and in May and July 2008. In the remaining months, the weather conditions were optimal for the growth and development of plants. It needs to be stressed that in Olszanica (s2) the moisture conditions were more favorable for the growth of the analyzed species.

\section{Results}

The development of roots of the tested species depended on all the factors: sowing method, soil, and also growing season (Tab. 1).

Peas growing on Luvic Phaeozem developed smaller roots with a lower biomass, as compared to Eutric Cambisol (Tab. 1). Also, different soil conditions influenced the adaptation of pea to the sowing method. When pea was grown on chernozem, the root parameters were better for the sole crop, whereas growing peas on Eutric Cambisol resulted in significantly better root development in the mixture. Among the tested root parameters, the MRD turned out to be susceptible to the method of pea sowing: pea grown in the mixtures on chernozem responded with a slightly decreased MRD, whereas when grown on Eutric Cambisol - a slightly increased MRD.

Regardless of the soil type, the root parameters of vetch were significantly lower when it was grown in the mixture with linseed. Especially strong effects of sowing method were observed in the 2006 growing season with less favorable weather conditions.

The roots of linseed reacted differently to the sowing method, depending on both the growing season and soil type. On Luvic Phaeozem, higher values of the root parameters were obtained for the mixtures with vetch or for pure sowing. Contrary to that, on Eutric Cambisol higher values were recorded for the mixtures with pea and also for pure sowing. Regardless of the soil type, the RDW of linseed was significantly higher when it was grown in both mixtures.

The analysis of variance showed that the effect of mixed cropping on the root to shoot ratio was significant. Species in pure sowing have a significantly higher root shoot ratio than species in mixtures. The effect of soil type on RSR was stronger on Luvic Phaeozem and indicated a consistently higher value of RSR in pure sowing in comparison with Eutric Cambisol (Tab. 1).
Overall, the RLD and the MRD decreased with increasing soil depth and this observation was similar for all the crops tested, regardless of the sowing method (Fig. 2-Fig. 5). The largest proportion of root mass was concentrated in the $0-15 \mathrm{~cm}$ soil layer for all the crop species, regardless of the soil conditions. For all the species, roots in the class of $0.05-0.5 \mathrm{~mm}$ diameter accounted for about $60 \%$ of the total root length, while those in the class of $0.5-2.0 \mathrm{~mm}$ diameter for about $30 \%$. Larger diameter roots $(0.02-0.05 \mathrm{~mm})$ contributed only in a small proportion to the total root length.

The analysis of variance proved that the RLD was significantly influenced by the method of sowing. The roots of pea, grown as a sole crop, branched more in the top layer (up to $0-15 \mathrm{~cm}$ ). On the other hand, in the mixed crop the roots of pea branched more intensively in the deeper layer $(15-30 \mathrm{~cm})$. A detailed analysis of pea root distribution in the $0-30 \mathrm{~cm}$ layer showed that on average $60 \%$ of its roots belonged to the $0.1-0.5 \mathrm{~mm}$ class, irrespective of the sowing method. A higher variation in the root size was observed in the different soil types. In the top layer of Luvic Phaeozem (S1), higher (70\%) root elongation was observed in the $0.1-0.5 \mathrm{~mm}$ class for pea grown in the mixture. Also, a higher portion of root biomass $(80 \%)$ was observed in the same class $(0.1-0.5 \mathrm{~mm})$ for pea grown in the mixture, in the deeper layer of Eutric Cambisol (S2).

A significant variation in RLD for vetch was observed in the various classes and soil profiles (Fig. 3). In the top layer $(0-15 \mathrm{~cm})$, the RLD value was to a greater extent influenced by the sowing method than in the deeper layer. Approximately $60 \%$ of vetch roots in the top soil layer fit into the $0.1-0.5 \mathrm{~mm}$ class. Approximately $60 \%$ of vetch roots were better developed and thicker $(0.1-0.2 \mathrm{~mm})$ in the deeper soil layer when vetch was grown as a sole crop. A higher variation in vetch roots, caused by the method of sowing, was observed on Eutric Cambisol (S2). The sole crop of vetch was characterized by higher root fragmentation (0.05-0.2 mm), regardless of the soil layer. On the other hand, when grown in the mixture, vetch increased the root elongation in the $0.1-0.5 \mathrm{~mm}$ class, irrespective of the soil depth.

The root length of linseed was similar for all the sowing methods as well as for the soil type and soil layer (Fig. 3). In both the sole crop and the mixed crop, $70 \%$ of roots fit into the $0.05-0.2 \mathrm{~mm}$ class.

The MRD of all the species varied and depended on the sowing method, soil type and soil layer (Fig. 4, Fig. 5). 
Tab. 1 Root dry weight (RDW), root length density (RLD), and mean root diameter (MRD) of the roots profile $(0-30 \mathrm{~cm})$ at the flowering stage under the different methods of sowing and growing in different soils.

\begin{tabular}{|c|c|c|c|c|c|c|c|c|}
\hline \multirow[b]{2}{*}{$\begin{array}{l}\text { Growing season and } \\
\text { sowing method }\end{array}$} & \multicolumn{4}{|c|}{ Luvic Phaeozem (s1) } & \multicolumn{4}{|c|}{ Eutric Cambisol (s2) } \\
\hline & $\begin{array}{l}\text { RDW } \\
\left(\mathrm{g} \mathrm{cm}^{-3}\right)\end{array}$ & $\begin{array}{l}\text { RLD } \\
\left(\mathrm{mm} \mathrm{cm}^{-3}\right)\end{array}$ & $\begin{array}{l}\text { MRD } \\
(\mathrm{mm})\end{array}$ & RSR & $\begin{array}{l}\text { RDW } \\
\left(\mathrm{g} \mathrm{cm}^{-3}\right)\end{array}$ & 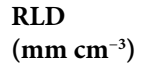 & $\begin{array}{l}\text { MRD } \\
(\mathbf{m m})\end{array}$ & RSR \\
\hline \multicolumn{9}{|l|}{ Pea } \\
\hline $\begin{array}{r}\mathrm{PL} \\
\mathrm{P}\end{array}$ & $\begin{array}{l}0.0017 \\
0.0026\end{array}$ & $\begin{array}{l}2.87 \\
2.05\end{array}$ & $\begin{array}{l}0.487 \\
0.209\end{array}$ & $\begin{array}{l}0.118 \\
0.163\end{array}$ & $\begin{array}{l}0.0118 \\
0.0032\end{array}$ & $\begin{array}{l}2.63 \\
3.34\end{array}$ & $\begin{array}{l}0.546 \\
0.596\end{array}$ & $\begin{array}{l}0.476 \\
0.243\end{array}$ \\
\hline $\begin{array}{r}\mathrm{PL} \\
\mathrm{P}\end{array}$ & $\begin{array}{l}0.0015 \\
0.0028\end{array}$ & $\begin{array}{l}2.25 \\
1.80\end{array}$ & $\begin{array}{l}0.155 \\
0.337\end{array}$ & $\begin{array}{l}0.106 \\
0.157\end{array}$ & $\begin{array}{l}0.0075 \\
0.0052\end{array}$ & $\begin{array}{l}2.31 \\
2.45\end{array}$ & $\begin{array}{l}0.156 \\
0.366\end{array}$ & $\begin{array}{l}0.229 \\
0.123\end{array}$ \\
\hline $\begin{array}{r}\mathrm{PL} \\
\mathrm{P}\end{array}$ & $\begin{array}{l}0.0026 \\
0.0037\end{array}$ & $\begin{array}{l}1.71 \\
2.36\end{array}$ & $\begin{array}{l}0.158 \\
0.517\end{array}$ & $\begin{array}{l}0.209 \\
0.311\end{array}$ & $\begin{array}{l}0.0041 \\
0.0047\end{array}$ & $\begin{array}{l}2.22 \\
2.33\end{array}$ & $\begin{array}{l}0.449 \\
0.211\end{array}$ & $\begin{array}{l}0.277 \\
0.270\end{array}$ \\
\hline $\begin{array}{l}\text { Mean } \\
\text { PL } \\
\text { PL:P S.E.D. }(\text { D.F. }=28)\end{array}$ & $\begin{array}{l}0.0019 \pm 0.00034 \\
0.0030 \pm 0.00034 \\
0.0003^{* *}\end{array}$ & $\begin{array}{l}2.28 \pm 0.33 \\
2.03 \pm 0.16 \\
0.169\end{array}$ & $\begin{array}{l}0.267 \pm 0.11 \\
0.354 \pm 0.09 \\
0.072\end{array}$ & $\begin{array}{l}0.144 \pm 0.03 \\
0.210 \pm 0.05 \\
0.031^{\star}\end{array}$ & $\begin{array}{l}0.0078 \pm 0.002 \\
0.0044 \pm 0.0006 \\
0.0012^{\star}\end{array}$ & $\begin{array}{l}2.39 \pm 0.12 \\
2.71 \pm 0.32 \\
0.121^{*}\end{array}$ & $\begin{array}{l}0.384 \pm 0.12 \\
0.391 \pm 0.11 \\
0.05\end{array}$ & $\begin{array}{l}0.327 \pm 0.07 \\
0.212 \pm 0.04 \\
0.036^{* \star}\end{array}$ \\
\hline \multicolumn{9}{|l|}{ Vetch } \\
\hline $\begin{array}{r}\text { VL } \\
\text { V }\end{array}$ & $\begin{array}{l}0.0017 \\
0.0038\end{array}$ & $\begin{array}{l}1.90 \mathrm{a} \\
2.67 \mathrm{~b}\end{array}$ & $\begin{array}{l}0.438 \mathrm{a} \\
0.629 \mathrm{~b}\end{array}$ & $\begin{array}{l}0.557 \\
0.670\end{array}$ & $\begin{array}{l}0.0017 \mathrm{a} \\
0.0226 \mathrm{~b}\end{array}$ & $\begin{array}{l}1.67 \mathrm{a} \\
2.23 \mathrm{~b}\end{array}$ & $\begin{array}{l}0.332 \mathrm{a} \\
0.667 \mathrm{~b}\end{array}$ & $\begin{array}{l}0.251 \\
0.897\end{array}$ \\
\hline $\begin{array}{r}\text { VL } \\
\text { V }\end{array}$ & $\begin{array}{l}0.0021 \\
0.0029\end{array}$ & $\begin{array}{l}1.99 \mathrm{a} \\
2.25 \mathrm{~b}\end{array}$ & $\begin{array}{l}0.135 \mathrm{a} \\
0.926 \mathrm{~b}\end{array}$ & $\begin{array}{l}0.288 \\
0.404\end{array}$ & $\begin{array}{l}0.0015 \mathrm{a} \\
0.0294 \mathrm{~b}\end{array}$ & $\begin{array}{l}1.27 \mathrm{a} \\
1.81 \mathrm{~b}\end{array}$ & $\begin{array}{l}0.222 \mathrm{~b} \\
0.178 \mathrm{a}\end{array}$ & $\begin{array}{l}0.254 \\
0.685\end{array}$ \\
\hline $\begin{array}{r}\text { VL } \\
\mathrm{V}\end{array}$ & $\begin{array}{l}0.0021 \\
0.0029\end{array}$ & $\begin{array}{l}2.40 \mathrm{a} \\
2.41 \mathrm{a}\end{array}$ & $\begin{array}{l}0.133 \mathrm{a} \\
0.626 \mathrm{~b}\end{array}$ & $\begin{array}{l}0.582 \\
0.523\end{array}$ & $\begin{array}{l}0.0024 \mathrm{a} \\
0.0178 \mathrm{~b}\end{array}$ & $\begin{array}{l}1.39 \mathrm{a} \\
1.98 \mathrm{~b}\end{array}$ & $\begin{array}{l}0.299 \mathrm{a} \\
0.343 \mathrm{~b}\end{array}$ & $\begin{array}{l}0.448 \\
0.821\end{array}$ \\
\hline $\begin{array}{cr}\text { Mean } & \mathrm{VL} \\
& \mathrm{V} \\
\text { VL:V S.E.D. }(D . F .=28)\end{array}$ & $\begin{array}{l}0.0020 \pm 0.0001 \\
0.0032 \pm 0.0004 \\
0.0003^{* *}\end{array}$ & $\begin{array}{l}2.09 \pm 0.15 \\
2.44 \pm 0.12 \\
0.109^{* *}\end{array}$ & $\begin{array}{l}0.235 \pm 0.101 \\
0.729 \pm 0.09 \\
0.065\end{array}$ & $\begin{array}{l}0.475 \pm 0.09 \\
0.532 \pm 0.08 \\
0.051\end{array}$ & $\begin{array}{l}0.0019 \pm 0.0003 \\
0.023 \pm 0.003 \\
0.028^{* \star}\end{array}$ & $\begin{array}{l}1.50 \pm 0.19 \\
1.96 \pm 0.12 \\
0.096^{* \star}\end{array}$ & $\begin{array}{l}0.286 \pm 0.03 \\
0.396 \pm 0.14 \\
0.044^{*}\end{array}$ & $\begin{array}{l}0.318 \pm 0.06 \\
0.801 \pm 0.06 \\
0.038^{\star \star}\end{array}$ \\
\hline Linseed & & & & & & & & \\
\hline $\begin{array}{r}\text { LP } \\
\mathrm{LV} \\
\mathrm{L}\end{array}$ & $\begin{array}{l}0.0006 \\
0.0005 \\
0.0015\end{array}$ & $\begin{array}{l}2.15 \\
2.70 \\
2.49\end{array}$ & $\begin{array}{l}0.521 \\
0.573 \\
0.341\end{array}$ & $\begin{array}{l}0.220 \\
0.125 \\
0.131\end{array}$ & $\begin{array}{l}0.0012 \\
0.0005 \\
0.0004\end{array}$ & $\begin{array}{l}3.08 \\
2.35 \\
3.59\end{array}$ & $\begin{array}{l}0.405 \\
0.564 \\
0.404\end{array}$ & $\begin{array}{l}1.999 \\
0.074 \\
0.093\end{array}$ \\
\hline $\begin{array}{r}\mathrm{LP} \\
\mathrm{LV} \\
\mathrm{L}\end{array}$ & $\begin{array}{l}0.0027 \\
0.0014 \\
0.0018\end{array}$ & $\begin{array}{l}1.48 \\
2.04 \\
1.66\end{array}$ & $\begin{array}{l}0.726 \\
0.734 \\
1.142\end{array}$ & $\begin{array}{l}0.288 \\
0.082 \\
0.348\end{array}$ & $\begin{array}{l}0.0031 \\
0.0004 \\
0.0033\end{array}$ & $\begin{array}{l}3.02 \\
1.61 \\
2.86\end{array}$ & $\begin{array}{l}0.349 \\
0.363 \\
0.315\end{array}$ & $\begin{array}{l}0.666 \\
0.161 \\
0.378\end{array}$ \\
\hline $\begin{array}{r}\mathrm{LP} \\
\mathrm{LV} \\
\mathrm{L}\end{array}$ & $\begin{array}{l}0.0012 \\
0.0014 \\
0.0030\end{array}$ & $\begin{array}{l}1.65 \\
2.35 \\
1.58\end{array}$ & $\begin{array}{l}0.260 \\
0.552 \\
0.350\end{array}$ & $\begin{array}{l}0.416 \\
0.129 \\
0.718\end{array}$ & $\begin{array}{l}0.0019 \\
0.0004 \\
0.0006\end{array}$ & $\begin{array}{l}2.98 \\
1.94 \\
2.73\end{array}$ & $\begin{array}{l}0.234 \\
0.332 \\
0.258\end{array}$ & $\begin{array}{l}0.329 \\
0.088 \\
0.098\end{array}$ \\
\hline $\begin{array}{r}\mathrm{LP} \\
\mathrm{LV} \\
\mathrm{L}\end{array}$ & $\begin{array}{l}0.0015 \pm 0.0006 \\
0.0011 \pm 0.00005 \\
0.0021 \pm 0.0004\end{array}$ & $\begin{array}{l}1.76 \pm 0.20 \\
2.37 \pm 0.19 \\
1.91 \pm 0.29\end{array}$ & $\begin{array}{l}0.504 \pm 0.13 \\
0.620 \pm 0.06 \\
0.612 \pm 0.26\end{array}$ & $\begin{array}{l}0.307 \pm 0.06 \\
0.112 \pm 0.01 \\
0.399 \pm 0.17\end{array}$ & $\begin{array}{l}0.0021 \pm 0.0005 \\
0.0011 \pm 0.00005 \\
0.0014 \pm 0.0015\end{array}$ & $\begin{array}{l}3.03 \pm 0.03 \\
1.97 \pm 0.21 \\
3.06 \pm 0.27\end{array}$ & $\begin{array}{l}0.329 \pm 0.05 \\
0.419 \pm 0.07 \\
0.325 \pm 0.04\end{array}$ & $\begin{array}{l}0.998 \pm 0.51 \\
0.108 \pm 0.02 \\
0.189 \pm 0.09\end{array}$ \\
\hline LP:LV:L S.E.D. $($ D.F. $=41)$ & $0.0004^{\star *}$ & $0.079^{* *}$ & 0.064 & $0.054^{\star *}$ & $0.0003^{\star *}$ & $0.11^{* *}$ & 0.064 & $0.057^{\star \star}$ \\
\hline
\end{tabular}

L - linseed; V - vetch; P - pea; PL - pea + linseed; VL - vetch + linseed; $\mathrm{LP}$ - linseed + pea; VL - vetch + pea. ${ }^{\star}$ Denotes significant differences at $P \leq 0.05$. ${ }^{* *}$ Denotes significant differences at $P \leq 0.01$. ns - not significant differences.

Higher values of the root diameter in Luvic Phaeozem were noticed for both legume species, while linseed roots were thicker when grown in Eutric Cambisol.

Pea grown as a pure crop developed thicker roots (0.2$0.1 \mathrm{~mm}$ ); in the mixture with linseed, the root diameter decreased to the $0.5-1.0 \mathrm{~mm}$ class and $0.1-0.5$ class in Luvic Phaeozem and Eutric Cambisol, respectively (Fig. 4).

The diameter of vetch roots was affected by the method of sowing only in Luvic Phaeozem. The results indicate that the MRD values for vetch increased in the sole crop and reached the $0.5-2.0 \mathrm{~mm}$ class, while in the mixture decreased to the 0.1-0.5 mm class. In the top layer of Chernozem (S1) and in the sole crop, the diameter of $80 \%$ of vetch roots fitted into the 0.05-0.5 mm class. In Eutric Cambisol (S2), approximately $60 \%$ of root biomass belonged to the $0.2-1.0 \mathrm{~mm}$ class, regardless of the method of sowing and soil layer, and only $15 \%$ of root biomass belonged to the $0.05-0.2 \mathrm{~mm}$ class.

The MRD of linseed was affected by both the sowing method and soil type (Fig. 4). On average, $60 \%$ of linseed root biomass in pure sowing in the top layer fitted into the $0.1-0.5 \mathrm{~mm}$ class. In the case of both legume species, mixed sowing led to a significant decrease in root diameter to $0.05-0.2 \mathrm{~mm}$. In the sole crop or in the mixture with vetch, in the deeper soil layer $60 \%$ of linseed root diameter was in the 0.2 to $1.0 \mathrm{~mm}$ class. In the top layer of Eutric Cambisol (S2), approximately $60 \%$ of linseed root diameter in the sole crop was in the 0.1 to $0.5 \mathrm{~mm}$ class. Linseed grown in mixtures exhibited higher MRD, up to the $0.2-0.1 \mathrm{~mm}$ class. In the deeper soil layer, approximately $60 \%$ of linseed roots belonged to the $0.1-0.5 \mathrm{~cm}$ class, regardless of the method of sowing. 

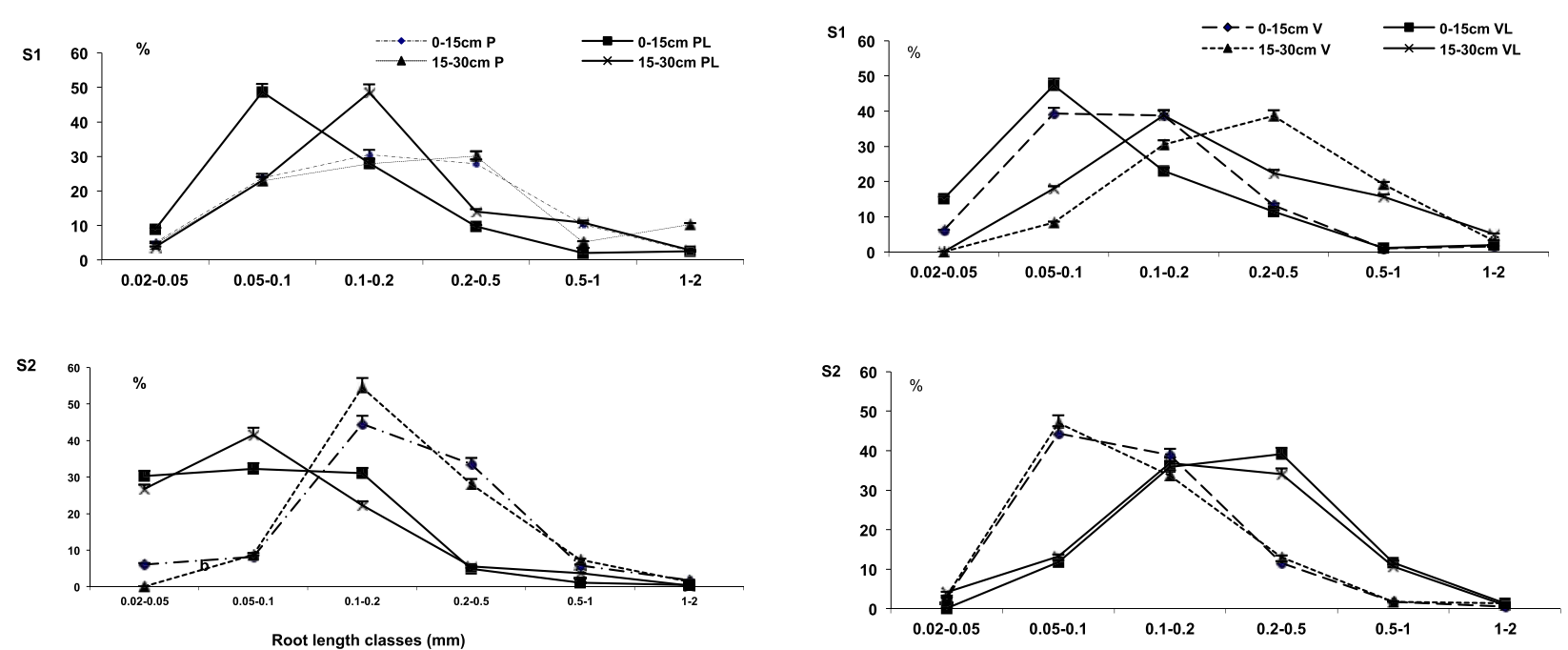

Fig. 2 Classes of root length density in the $0-15 \mathrm{~cm}$ and $15-30 \mathrm{~cm}$ soil profile depending on the method of sowing; sole crop of pea - P, mixed crop of pea with linseed PL, sole crop of vetch - V, mixed crop of vetch and linseed VL in Luvic Phaeozem (S1) and Eutric Cambisol (S2); averages for 2006-2008.


Fig. 3 Classes of root length density in the $0-15 \mathrm{~cm}$ and $15-30 \mathrm{~cm}$ soil profile depending on the method of sowing; sole crop of linseed - L, mixed crop with pea LP, mixed crop with vetch LV in Luvic Phaeozem (S1) and Eutric Cambisol (S2); averages for 2006-2008.

In relation to the accumulation of dry matter in roots, the RNE in both mixtures was proportional to the root biomass of each species in the mixtures (Tab. 2). The performance parameter (RNE) for the species in the mixtures ranged in Luvic Phaeozem from 0.48 in the mixture of linseed with pea to -0.48 in the mixture of vetch with linseed, while in Eutric Cambisol from 0.36 in the mixture of pea with linseed to -0.59 in the mixture of linseed with vetch. In Luvic Phaeozem the RNE was negative for linseed in the mixture with vetch, which indicated facilitation for species in the mixture. In Eutric Cambisol the RNE had positive values for pea and linseed in the mixture, while for the mixture of vetch and linseed the value was negative (Tab. 2). The positive value of RNE for pea in mixture with linseed and for linseed in mixture with pea indicated the mutual competition effect.

In our experiment, $A_{\text {vetch }}$ and $A_{\text {pea }}$ were negative, whereas the values of $A_{\text {linseed }}$ were positive (Tab. 2). These results show that linseed was the dominant species in the mixture with vetch or pea. The higher $A_{\text {linseed }}$ value in the mixture with pea or vetch was observed regardless of the soil type.
The negative value of $K_{\mathrm{L}: \mathrm{V}}$ indicates strong competitiveness of linseed (L) against vetch (V). The competitiveness of pea and linseed in the mixture was soil dependent; in Luvic Phaeozem the value of $K_{\mathrm{L}: \mathrm{P}}$ was negative and indicated stronger competitiveness of linseed, while in Eutric Cambisol pea was more competitive. The positive values of $K_{\mathrm{V}: \mathrm{L}}$, regardless of the type of soil, indicated weak interspecific competitiveness of vetch in the mixture with linseed.

The seed yield varied depending on the sowing method and soil type (Tab. 3 ). The total seed yield was $9.14 \mathrm{~g}$ per plant for pea in pure sowing, while it was $7.72 \mathrm{~g}$ per plant for pea mixed with linseed in Eutric Cambisol. In Luvic Phaeozem the seed yield was slightly lower and for pea it was $8.40 \mathrm{~g}$ in pure sowing, while in mixture it reached $7.46 \mathrm{~g}$. The yield of vetch was lower and reached $2.40 \mathrm{~g}$ per plant for pure crop and $1.87 \mathrm{~g}$ per plant for mixture in Eutric Cambisol. In Luvic Phaeozem the seed yield of vetch was $2.38 \mathrm{~g}$ per plant in pure sowing and $2.05 \mathrm{~g}$ per plant for mixture. In Eutric Cambisol, linseed produced the lowest yields in the mixtures with pea, while in Luvic Phaeozem it gave the lowest yield 

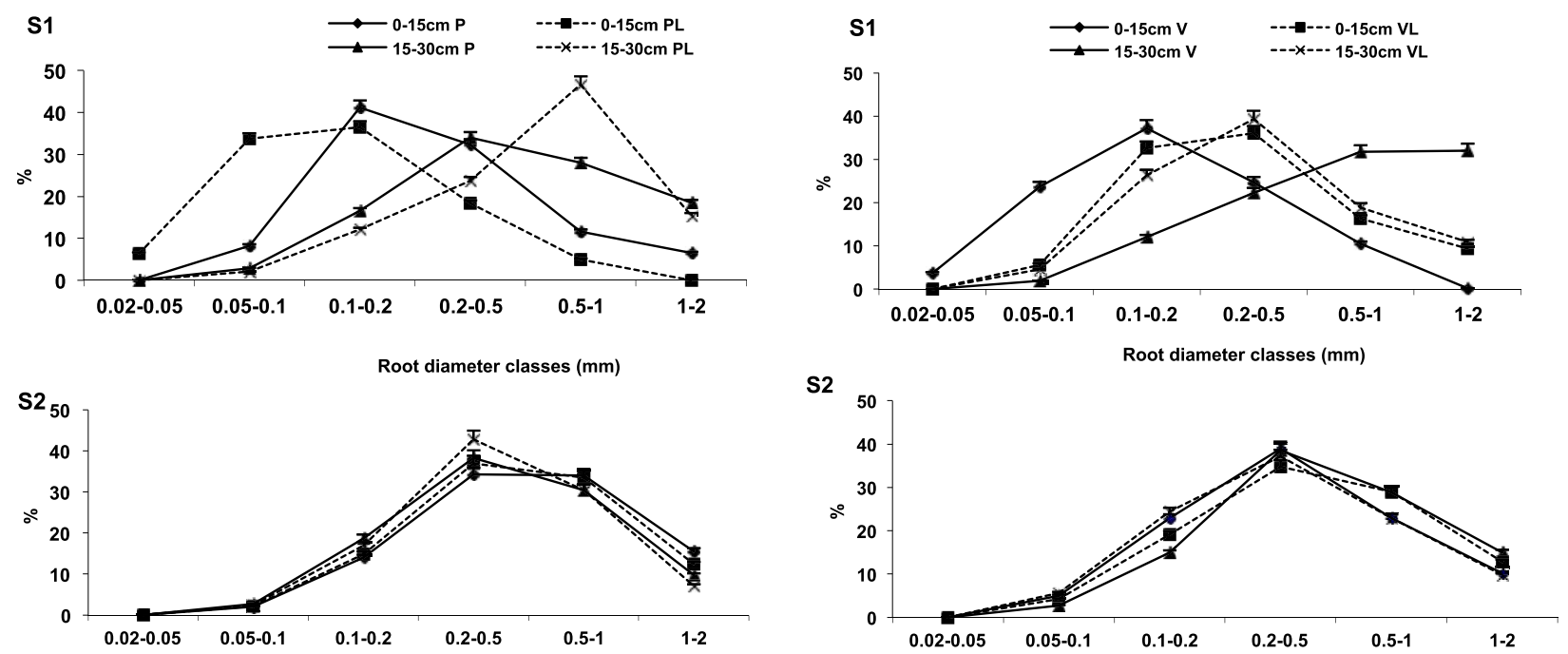

Fig. 4 Classes of mean root diameter in the $0-15 \mathrm{~cm}$ and $15-30 \mathrm{~cm}$ soil profile depending on the method of sowing: sole crop of pea - P, mixed crop with linseed PL, vetch:sole crop of vetch - V, mixed crop with linseed VL in Luvic Phaeozem (S1) and Eutric Cambisol (S2), averages for 2006-2008. Different letters denote significant differences at $P \leq 0.05$.
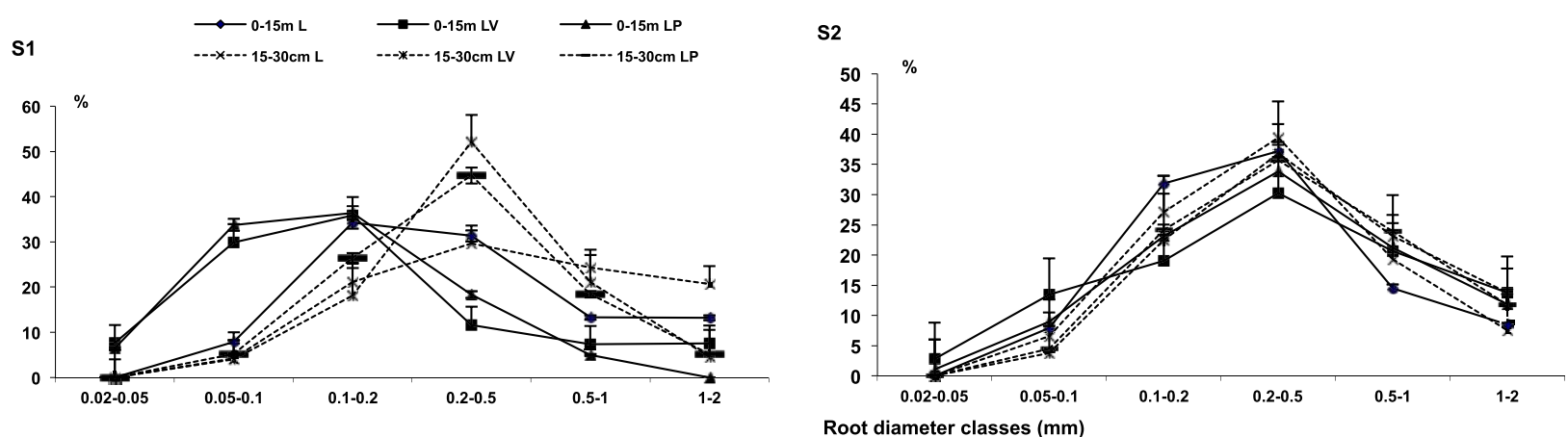

Fig. 5 Classes of mean root diameter in the $0-15 \mathrm{~cm}$ and $15-30 \mathrm{~cm}$ soil profile, depending on the method of sowing: linseed (L) in sole crop, mixed crop with pea - LP, mixed crop with vetch - LV in Luvic Phaeozem (S1) and Eutric Cambisol (S2), averages for 2006-2008.

in mixture with vetch. There was a significant interaction between treatments in years for the compared soils. In Luvic Phaeozem, in both 2007 and 2008 pure sowing significantly increased the seed yield for all the investigated species, while in Eutric Cambisol the highest seed yield was obtained for pea in pure sowing, with the exception in 2006.

\section{Discussion}

The relation between the morphological characteristics of roots and soil conditions indicates a wide array of mutual relationships. Our experiment proved that the RDW of linseed, pea and vetch depends on the method of sowing and soil type. In Luvic Phaeozem, the highest root dry mass was recorded for vetch sown as a pure crop, while in the mixture pea obtained the highest root mass. In Eutric Cambisol, pea, grown both in mixture with linseed and as a sole crop, obtained the greatest root dry weight.
Itoh et al. [22] proved that the root mass of plants depends on soil and water conditions, which change annually. The authors suggest that, compared to heavy soils, moderately rich soils provide better conditions for the development of root mass. Our research showed that the sowing method significantly affects the total root mass of legumes in better water conditions (Eutric Cambisol), while for the roots of linseed this impact is smaller.

Głab et al. [23] and Ndakidemi [13] describe the interactions between the root systems of plants, both in sole crops or in mixtures, proving that the physical properties of roots change when plants coexist. In the present study, legumes developed greater root length density under low soil moisture conditions - Luvic Phaeozem, while linseed under higher soil moisture conditions - Eutric Cambisol. This could be related to the amount of water needed for seed development: legume plants with a high transpiration index tend to develop a deeper root system, searching for water. Additionally, in Luvic Phaeozem legumes grown as 
Tab. 2 Relative neighbor effect (RNE), aggressivity $(A)$, and crowding coefficient $(K)$ for roots of linseed and legumes (pea or vetch) grown in mixtures.

\begin{tabular}{|c|c|c|c|c|c|c|c|}
\hline \multirow{2}{*}{\multicolumn{2}{|c|}{ Year / Treatment }} & \multicolumn{3}{|c|}{ Luvic Phaeozem (s1) } & \multicolumn{3}{|c|}{ Eutric Cambisol (s2) } \\
\hline & & RNE & $A$ & $K$ & RNE & $A$ & $K$ \\
\hline 2006 & \multirow[t]{4}{*}{$\mathrm{P}: \mathrm{L}$} & $0.15 \mathrm{a}^{*}$ & $-3.97 \mathrm{a}$ & $0.83 \mathrm{a}$ & $-0.22 \mathrm{a}$ & $-0.74 \mathrm{a}$ & $-2.22 \mathrm{a}$ \\
\hline 2007 & & $0.15 \mathrm{a}$ & $-6.30 \mathrm{~b}$ & $0.59 \mathrm{a}$ & $0.05 \mathrm{~b}$ & $-0.09 \mathrm{~b}$ & $-1.74 \mathrm{a}$ \\
\hline 2008 & & $0.09 \mathrm{~b}$ & $-1.12 \mathrm{c}$ & $0.18 \mathrm{~b}$ & $0.18 \mathrm{~b}$ & $-0.61 \mathrm{c}$ & $2.04 \mathrm{~b}$ \\
\hline $\pm S D$ & & $0.13 \pm 0.02$ & $3.80 \pm 1.49$ & $0.53 \pm 0.19$ & $0.003 \pm 0.05$ & $-0.48 \pm 0.19$ & $-2.67 \pm 0.14$ \\
\hline 2006 & \multirow[t]{4}{*}{$\mathrm{V}: \mathrm{L}$} & $0.18 \mathrm{a}$ & $-1.50 \mathrm{a}$ & $0.39 \mathrm{a}$ & $-0.59 \mathrm{a}$ & $-6.47 \mathrm{a}$ & $1.87 \mathrm{a}$ \\
\hline 2007 & & $0.41 \mathrm{a}$ & $-1.64 \mathrm{a}$ & $0.56 \mathrm{a}$ & $0.04 \mathrm{~b}$ & $0.17 \mathrm{~b}$ & $0.92 \mathrm{~b}$ \\
\hline 2008 & & $-0.48 \mathrm{~b}$ & $-0.57 b$ & $0.28 \mathrm{a}$ & $-0.39 c$ & $-1.13 \mathrm{a}$ & $1.61 \mathrm{a}$ \\
\hline $\pm S D$ & & $0.03 \pm 0.09$ & $-1.24 \pm 0.33$ & $0.41 \pm 0.08$ & $-0.313 \pm 0.16$ & $-2.48 \pm 1.95$ & $1.46 \pm 0.28$ \\
\hline 2006 & \multirow[t]{4}{*}{$\mathrm{L}: \mathrm{P}$} & $-0.009 \mathrm{a}$ & $3.97 \mathrm{a}$ & $9.56 \mathrm{a}$ & $-0.04 \mathrm{a}$ & $0.74 \mathrm{a}$ & $-1.27 \mathrm{a}$ \\
\hline 2007 & & $0.48 \mathrm{~b}$ & $6.30 \mathrm{~b}$ & $-4.58 \mathrm{~b}$ & $0.11 b$ & $0.09 \mathrm{~b}$ & $1.22 \mathrm{~b}$ \\
\hline 2008 & & $-0.07 \mathrm{c}$ & $1.12 \mathrm{c}$ & $-7.69 b$ & $0.36 \mathrm{~b}$ & $0.61 \mathrm{a}$ & $4.21 \mathrm{c}$ \\
\hline $\pm S D$ & & $0.133 \pm 0.15$ & $3.80 \pm 1.49$ & $-0.90 \pm 1.45$ & $0.143 \pm 0.09$ & $0.48 \pm 0.19$ & $2.20 \pm 0.99$ \\
\hline 2006 & \multirow[t]{4}{*}{$\mathrm{L}: \mathrm{V}$} & $-0.05 \mathrm{a}$ & $1.50 \mathrm{a}$ & $5.58 \mathrm{a}$ & $-0.59 \mathrm{a}$ & $6.46 \mathrm{a}$ & $-4.66 \mathrm{a}$ \\
\hline 2007 & & $-0.46 \mathrm{~b}$ & $1.64 \mathrm{a}$ & $-4.30 \mathrm{~b}$ & $-0.02 \mathrm{~b}$ & $-0.17 \mathrm{~b}$ & $-4.75 \mathrm{a}$ \\
\hline 2008 & & $0.01 \mathrm{c}$ & $0.57 \mathrm{~b}$ & $-8.36 \mathrm{~b}$ & $0.17 \mathrm{c}$ & $1.13 \mathrm{c}$ & $7.21 \mathrm{~b}$ \\
\hline $\pm S D$ & & $-0.167 \pm 0.14$ & $1.24 \pm 0.33$ & $-2.36 \pm 1.20$ & $-0.147 \pm 0.17$ & $2.47 \pm 1.95$ & $-0.73 \pm 0.83$ \\
\hline
\end{tabular}

L - linseed; V - vetch; P - pea; PL - pea + linseed; VL - vetch + linseed; LP - linseed + pea; VL - vetch + pea,

${ }^{\star}$ Mean values with the same letter are not different at $5 \%$ probability level.

Tab. 3 Effect of sowing method on seed yield during the three years of the experiment.

\begin{tabular}{|c|c|c|c|c|c|c|c|c|c|c|}
\hline \multirow[b]{2}{*}{$\begin{array}{l}\text { Yield } \\
\text { (plant g-1) }\end{array}$} & \multicolumn{5}{|c|}{ Luvic Phaeozem (s1) } & \multicolumn{5}{|c|}{ Eutric Cambisol (s2) } \\
\hline & 2006 & 2007 & 2008 & Mean & $\begin{array}{c}\text { S.D. } \\
(D . F .=10)\end{array}$ & 2006 & 2007 & 2008 & Mean & $\begin{array}{c}\text { S.D. } \\
(D . F .=10)\end{array}$ \\
\hline PL & 6.25 & 7.48 & 8.65 & 7.46 & $0.51^{*}$ & 9.31 & 7.88 & 5.97 & 7.72 & $0.34^{*}$ \\
\hline P & 8.22 & 8.20 & 8.77 & 8.40 & 0.59 & 9.15 & 10.40 & 7.86 & 9.14 & $0.43^{*}$ \\
\hline Mean & 7.23 & 7.84 & 8.71 & & & 9.23 & 9.14 & 6.91 & & \\
\hline S.D. $(D . F .=6)$ & $0.32^{*}$ & 0.81 & 0.42 & & & ns & 0.32 & 0.50 & & \\
\hline $\mathrm{VL}$ & 1.23 & 2.67 & 2.24 & 2.05 & $0.31^{*}$ & 1.85 & 2.77 & 2.57 & 2.40 & $0.30^{*}$ \\
\hline V & 1.47 & 3.00 & 2.67 & 2.38 & $0.42^{*}$ & 1.68 & 2.41 & 1.53 & 1.87 & $0.12^{*}$ \\
\hline Mean & 1.35 & 2.84 & 2.46 & & & 1.77 & 2.59 & 2.05 & & \\
\hline S.D. & $0.05^{*}$ & 0.63 & $0.13^{*}$ & & & $0.05^{*}$ & 0.35 & $0.17^{*}$ & & \\
\hline LP & 1.20 & 1.54 & 1.72 & 1.48 & $0.16^{*}$ & 1.09 & 1.54 & 1.20 & 1.28 & $0.12^{*}$ \\
\hline LV & 1.30 & 1.05 & 1.43 & 1.26 & $0.13^{*}$ & 1.30 & 1.05 & 1.55 & 1.30 & $0.09^{*}$ \\
\hline $\mathrm{L}$ & 1.23 & 1.29 & 1.74 & 1.42 & $0.03^{*}$ & 1.38 & 1.67 & 1.43 & 1.49 & $0.09^{*}$ \\
\hline Mean & 1.24 & 1.29 & 1.63 & & & 1.25 & 1.42 & 1.39 & & \\
\hline S.D. & 0.12 & $0.12^{\star}$ & 0.13 & & & $0.0^{*}$ & $0.14^{*}$ & $0.01^{*}$ & & \\
\hline
\end{tabular}

L - linseed; V - vetch; P - pea; PL - pea + linseed; VL - vetch + linseed; $\mathrm{LP}$ - linseed + pea; $\mathrm{VL}$ - vetch + pea. * Denotes significant differences at $P \leq 0.05$.

a sole crop produced greater root length density $(5.3 \mathrm{~mm}$ $\mathrm{cm}^{-3}$ and $4.43 \mathrm{~mm} \mathrm{~cm}^{-3}$, vetch and pea, respectively), while linseed developed longer roots when grown in the mixture with vetch $\left(4.98 \mathrm{~mm} \mathrm{~cm}^{-3}\right)$. On the other hand, in Eutric Cambisol, linseed reached the greatest root length density in pure sowing $\left(5.06 \mathrm{~mm} \mathrm{~cm}^{-3}\right)$, while in the mixture - pea $\left(4.17 \mathrm{~mm} \mathrm{~cm}^{-3}\right)$. Liu et al. [24] indicate that oilseed species have stronger ability for water uptake and nutrient acquisition than pulse crops. Pulse crops rely heavily on symbiotic $\mathrm{N}$-fixation as the main $\mathrm{N}$ source, whereas wheat and oilseeds rely on $\mathrm{N}$ supplied through inorganic fertilizers that are usually applied in the top soil layers. The higher number of extra-fine roots in oilseeds may improve the uptake of nutrients from the top soil layers. 
Fageria [14] claims that the root system development is particularly important in drought conditions, especially after sowing or during flowering. It is believed that water and nutrient uptake is determined by root morphology and distribution of branches. A significant variation in root development was observed in our research, depending on the weather conditions. A better development of the root system for pea and vetch was observed under higher moisture conditions in Eutric Cambisol. At the same time, both legumes, as a pure crop, were more sensitive to the lack of water during the flowering stage. The mixture of pea and linseed was also more sensitive to drought. This study confirms the results obtained by Wright and Rao [25] and Liu [24] showing that drought resistance may be improved by proper selection of species in mixtures, taking into account the soil and climatic conditions. Matusi and Singh [26] as well as Taiz and Zeiger [27] argue that the RLD index is a helpful tool in classification of plant susceptibility to drought. Liu [24] found that a lower amount of water in the top soil layer, up to $20 \mathrm{~cm}$, stimulated the root biomass production in pea and, as a result, better RLD. Ge et al. [28] and Wang et al. [29] demonstrated that plants with root systems concentrated in the topsoil are more likely to exhibit superior nutrient acquisition efficiency than plants with more deeply distributed roots.

Xie et al. [30] claimed that MRD is one of the most proper measures of the influence of the environment on root development. Waisel and Eshel [31] found that the amount of aboveground dry mass is impacted by the root diameter. The larger root diameter, the higher is the biomass increase due to improved transport of water and nutrients. Additionally, a higher root diameter contributes to the storage of resources and support of the weaker roots. On the other hand, a lower root diameter creates an active surface responsible for water and nutrient exchange. Bengough et al. [32] claimed that thicker roots are proven to have greater ability to penetrate soil, thus they greatly influence the physical properties of soil. In the present study, the MRD varied, depending on the sowing method and soil type. The average root diameter in Luvic Phaeozem was higher for all species grown as a pure crop: pea $(0.40 \mathrm{~mm})$, vetch $(0.38 \mathrm{~mm})$, linseed $(0.32 \mathrm{~mm})$. In Eutric Cambisol, in the mixture a higher root diameter was reached by pea $(0.40 \mathrm{~mm})$, while in the sole crop by vetch. We found that the root diameter was formed by competition, especially in intercropping. In the top layer of soil in the sole crop of linseed, on average $60 \%$ of root biomass fit into the $0.1-0.5 \mathrm{~mm}$ class. The mixed sowing of linseed caused a significant decrease in root diameter to $0.05-0.2 \mathrm{~mm}$. Singh and Sainju [33] reported that the highest concentration of roots, especially fine roots, occurs near the soil surface where conditions are more favorable for root growth.

The RSR ratio increased in pure sowing in Luvic Phaeozem, while in Eutric Cambisol this was observed in the linseed-vetch mixture. Fisher and Dunham [34] found that the root-to-shoot ratio is influenced by environmental factors. The environmental stress of plants in mixtures increased the relative weight of roots, which resulted in a decrease in the root-shoot ratio. The results are in line with the findings of Xu et al. [35] and Głąb et al. [23] who found a relationship between water availability and RSR value. A decrease in water availability increased the root-shoot ratio for legumes.

Jensen et al. [36] noticed that root systems demonstrate a high level of plasticity of development in response to local heterogeneity of the soil profile and plant density. For intercropping, complementarities in root distribution between species are desirable to reduce competition. In our experiment, the type of soil strongly determined the level of interspecies competition. Legumes, when grown on Luvic Phaeozem, competed strongly with linseed. Contrary to that, on Eutric Cambisol the competitive potential of vetch against linseed was lower. The aggressivity $(A)$ level was species-specific and linseed was more antagonistic towards both legumes, irrespective of the soil type.

We observed a negative influence of species in the mixture on the root parameters, which is in line with the results of Banik et al. [37] and Lauk and Lauk [38] who found that pure sowing is better, as compared to mixed sowing, due to the higher root biomass. The interspecies competition in linseed significantly influenced the root weight. Linseed grown as a sole crop developed higher root biomass of lower density and of lower diameter.

Growing pea as a mixture on Eutric Cambisol, which is characterized by good water relations and nutrient content, led to decreased aggressivity $(A<0)$ and lower interspecies competition $(R N E>0)$. Still, peas grown in the mixture were characterized by worse root parameters, as compared to its sole crop.

\section{Conclusions}

The root morphology of pulse crops was significantly affected by methods of sowing and soil types. The root systems of the compared plants demonstrate a high level of development plasticity in response to local heterogeneity and sowing methods. In Eutric Cambisol, the root systems of pulse crops competed strongly with linseed, while in Luvic Phaeozem the competitive potential of linseed against pea was higher. In Luvic Phaeozem, vetch sown as a pure crop had the greatest root dry weight, root length density, and root diameter. In Eutric Cambisol pea, grown both in the mixture with linseed and as a pure crop, achieved the greatest root dry weight. Pea mixed with linseed increased the root weight twice comparing to pure sowing only in Eutric Cambisol. Vetch in the mixture showed strong aggressiveness against linseed, regardless of the soil type. A higher amount of rainfall during growth in Eutric Cambisol caused a decrease in the weight of linseed roots. Nonetheless, the situation is reversed in the case of pea, which proves that these plants show individual responses to sowing methods. In Eutric Cambisol, the environmental stress of plants in mixtures increased the relative weight of roots, which resulted in a decrease in the root-shoot ratio. The root diameter is formed by competition, especially in intercropping. In the sole crop of linseed, in the top layer of soil $60 \%$ of root biomass fitted the $0.1-0.5 \mathrm{~mm}$ class. The mixed sowing of linseed caused a significant decrease in root diameter to $0.05-0.2 \mathrm{~mm}$. Linseed and legumes produced a higher seed yield in pure crop, regardless of the soil type. 


\section{Acknowledgments}

Research supported by the Ministry of Science and Higher Education of Poland as the part of statutory activities of Department of Crop Production of University of Agriculture of Agriculture in Krakow.

\section{Authors' contributions}

The following declarations about authors' contributions to the research have been made: designing the experiment: AKK, TZ, BK; field research: AKK, data analysis; AKK, TK, TG; comments on the manuscript: AKK, TZ, BK, TG, AS, writing the manuscript; AKK, AS.

\section{Competing interests}

No competing interests have been declared.

\section{References}

1. Dapaah HK, Asafu-Agyei JN, Ennin SA, Yamoah C. Yield stability of cassava, maize, soya bean and cowpea intercrops. J Agric Sci. 2003;140:73-82.

2. Hauggard-Nielsen H, Auggard-Nielsen H, Andersen MK, Jornsgaard $\mathrm{B}$, Jensen ES. Density and relative frequency effects on competitive interactions and resource use in pea-barley intercrops. Field Crop Res. 2006;95:256-267. http://dx.doi.org/10.1016/j.fcr.2005.03.003

3. Kordas L. Energy and economic effects of reduced tillage in crop rotation. Acta Sci Pol Agric. 2005;4:51-59.

4. Anderson RL, Bowman RA, Nielsen DC, Vigil MF, Aiken RM, Benjamin JG. Alternative crop rotations for central Great Plains. J Prod Agric. 1999;12:95-99.

5. Campbell CA, Zentner RP, Seller F, Biederbeck VO, Leyshon AJ. Comparative effects of garin-lentil-wheat and monoculture wheat on crop production, $\mathrm{N}$ economy and $\mathrm{N}$ fertility in a Brown Chernozem. Can J Plant Sci. 1992;72:1091-1107. http://dx.doi.org/10.4141/cjps2011-067

6. Campbell CA, Zentner RP. Organic C accumulation in soil over 30 years in semiarid southwestern Saskatchewan - effect of crop rotations and fertilizers. Can J Soil Sci. 2000;80:179-192. http://dx.doi. org/10.4141/s99-028

7. Biederbeck VO, Zentner RP, Campbell CA. Soil microbial populations and activities as influenced by legume green fallowing in a semiarid loam. Soil Bio Biochem. 2005;37:1775-1784. http://dx.doi. org/10.1016/j.soilbio

8. Li L, Zhang FS, Li XL, Christie P, Sun JH, Yang SC. Interspecific facilitation of nutrient uptake by intercropped maize and faba bean. Nut Cyc Agroecosys. 2003;68:61-71. http://dx.doi. org/10.1023/A:1021885032241

9. Miller PR, Wadding J, McDonald CL, Derksen DA. Cropping sequence affects wheat productivity on the semiarid northern Great Plains. Can J Plant Sci. 2002;82:307-318. http://dx.doi.org/10.4141/P01-116

10. Zając T, Oleksy A, Stokłosa A, Klimek-Kopyra A, Kulig B. The development competition and productivity of linseed and pea-cultivars grown in a pure sowing or in a mixture. Eur J Agron. 2013;44:22-31. http://dx.doi.org/10.1016/j.eja.2012.08.001

11. Klimek-Kopyra A, Zając T, Rembilas K. Evaluation of cooperation effect in intercrops: experiment and mathematical model. Eur J Agron. 2013;51:9-17. http://dx.doi.org/10.1016/j.eja.2013.06.002

12. Gan YT, Wang J, Bing DJ, Miller PR, McDonald CL. Water use of pulse crops at various plant densities under fallow and stubble conditions in a semiarid environment. Can J Plant Sci. 2007;87:719-722. http:// dx.doi.org/10.4141/P06-117

13. Ndakidemi PA. Manipulating legume/cereal mixtures to optimize the above and below ground interactions in the traditional African cropping systems. Afr J Biotechnol. 2006;5:2526-2533. http://dx.doi. org/10.5897/AJB2006.000-5113

14. Fageria NK. Influence of dry matter and length of roots on growth of five field crops at varying soil zinc and copper levels. J Plant Nutr. 2004;27:1517-1523. http://dx.doi.org/10.1081/PLN-200025995

15. Uga Y, Sugimoto K, Ogawa S, Rane J, Ishitani M, Hara N, et al. Control of root system architecture by DEEPER ROOTING 1 increases rice yield under drought conditions. Nat Genet. 2013;45:1097-1102. http:// dx.doi.org/10.1038/ng.2725

16. Ingram KT, Bueno FD, Namuco OS, Beyrouty CA. Rice root traits for drought resistance and their genetic variation. In: Kirk GJ, editor. Rice roots: nutrient and water use. Manila: International Rice Research Institute; 1994. p. 67-70.

17. Markham JH, Chanway CP. Measuring plant neighbour effects. Funct Ecol. 1996;10:548-549.

18. Bhatti IH, Ahmad R, Jabbar A, Nazir MS, Mahmood T.. Competitive behaviour of component crops in different sesame-legume intercropping systems. Int J Agric Biol. 2006;8:165-167.

19. Wahla IH, Ahmad R, Ehsanullah A, Jabbar A. Competitive functions of components crops in some barley based intercropping systems. Int J Agric Biol. 2009;11:69-72.

20. de Witt CT. On competition. Verslagen van Landbouwkundige Onderzoekingen. 1960;66(8):1-82.

21. StatSoft Inc. STATISTICA (data analysis software system), version $10 ; 2011$.

22. Itoh H, Hayashi S, Nakajima T, Hayashi T, Yoshida H, Yamazaki K, et al. Effects of soil type, vertical root distribution and precipitation on grain yield of winter wheat. Plant Prod Sci. 2009;12:503-513. http:// dx.doi.org/10.1626/pps.12.503

23. Głąb T, Ścigalska B, Łanuz B. Effect of crop rotation on the root system morphology and productivity of triticale $(\times$ Triticosecale Wittm). J Agric Sci. 2014;152:642-654. http://dx.doi.org/10.1007/ s11738-012-1097-5

24. Liu L. Root systems of oilseed and pulse crops - morphology, distribution and growth patterns [MSc thesis]. Saskatoon, SK: University of Saskatchewan; 2009.

25. Wright GC, Rao NRC. Peanut water relations. In: Smartt J, editor. The groundnut crop. London: Chapman \& Hall; 1994.p. 281-325.

26. Matsui T, Singh BB. Root characteristics in cow- pea related to drought tolerance at the seedling stage. Exp Agric. 2003;39:29-38.

27. Taiz L, Zeiger E. Stress physiology. In: Taiz L, Zeiger E, editors. Plant physiology. Sunderland, MA: Sinauer; 2006. p. 671-681.

28. Ge Z, Rubio YG, Lynch JP. The importance of root gravitropism for inter-root competition and phosphorus acquisition efficiency: results from a geometric simulation model. Plant Soil. 2000;218:159-171. http://dx.doi.org/10.1023/A:1014987710937

29. Wang X, Yan Y, Liao H. Genetic improvement for phosphorus efficiency in soybean: a radical approach. Ann Bot. 2010;106:215-222. http://dx.doi.org/10.1093/aob/mcq029

30. Xie YH, An S, Wu BF, Wang WW. Density-dependent root morphology and root distribution in the submerged plant Vallisneria natans. Environ Exp Bot. 2006;57:195-200. http://dx.doi.org/10.1016/j.envexpbot

31. Waisel Y, Eshel A. Functional diversity of various constituents of a single root system. In: Waisel Y, Eshel A, Kafkafi U, editors. Plant roots, the hidden half. New York, NY: Marcel Dekker; 2002. p. 157-174.

32. Bengough AG, Bransby MF, Hans J, Mckenn SJ, Roberts TJ, Valentine TA. Root responses to soil physical conditions, growth dynamics from field to cell. J Exp Bot. 2006;57:437-447. http://dx.doi.org/10.1093/ jxb/erj003

33. Singh BP, Sainju UM. Soil physical and morphological properties and root growth. Hortic Sci. 1998;33:966-971.

34. Fisher NM, Dunham RJ. The relationships in sorghum-soybean cropping systems with different physiology of tropical field crops. In: Goldsworthy PR, Fisher NW, editors. Root morphology and nutrient uptake. New York, NY: John Wiley \& Sons; 1984. p. 85-117.

35. Xu B, Shan L, Li F, Jiang J. Seasonal and spatial root biomass and water use efficiency of four forage legumes in semiarid northwest China. Afr J Biotechnol. 2007;6:2708-2714.

36. Jensen ES, Ambus P, Bellostas N, Boisen S, Brisson N, Corre-Hellou $\mathrm{G}$, et al. Intercropping of cereals and grain legumes for increased production, weed control, improved product quality and prevention of $\mathrm{N}$-losses in European organic farming systems. In: Andreasen 
CB, Elsgaard L, Sørensen LS, Hansen G, editors. Proceedings. Tjele: Danish Research Centre for Organic Food and Farming, DARCOF; 2007. p. 180-181.

37. Banik P, Sasmal T, Ghosal PK, Bagchi DK. Evaluation of mustard (Brassica compestris var. toria) and legume intercropping under 1:1 and 2:1 row - replacemnet series system. J Agron Crop Sci. 2000;185:9-14.

38. Lauk R, Lauk E. Dual intercropping of common vetch and wheat or oats, effects on yields and interspecific competition. Agron Res. 2009;7:21-32.

\section{Pionowy rozkład systemu korzeniowego Inu oleistego (Linum usitatissimum L.) i roślin strączkowych w siewie czystym i mieszanym}

\section{Streszczenie}

Konkurencja korzeniowa międzygatunkowa roślin jadalnych o zasoby siedliska prowadzi w dłuższym okresie czasu do rozwoju zrównoważonego systemu rolnictwa. Siew mieszany roślin jest bardziej produktywny w stosunku do siewu czystego z uwagi na wykorzystanie morfologicznych różnic pomiędzy gatunkami. W siewie czystym warunki glebowe $\mathrm{w}$ istotny sposób kształtują biofizyczne zróżnicowanie roślin. Natomiast w siewie mieszanym konkurencja korzeni roślin o wodę i składniki pokarmowe jest nadrzędnie istotna, jednak w przypadku roślin wykształcających korzenie na różnych głębokościach, zasoby siedliska są lepiej wykorzystywane przez rośliny. System korzeniowy roślin oleistych i strączkowych przedstawia różny stopień plastyczności w zależności od lokalnej różnorodności profilu gleby oraz zagęszczenia roślin w łanie. Celem pracy była $(\boldsymbol{i})$ ocena cech morfologicznych systemu korzeniowego lnu oleistego, grochu siewnego i wyki siewnej w zależności od sposobu siewu: siew czysty lnu, grochu i wyki, siew mieszany lnu z grochem (I), lnu z wyką (II), (ii) ocena dystrybucji systemu korzeniowego roślin $\mathrm{w}$ różnych warunkach glebowych: A - czarnoziem, B - gleba brunatna właściwa oraz różnej głębokości $(0-15 \mathrm{~cm}, 15-30 \mathrm{~cm})$. W badaniach wykazano, że len oleisty wykształcił bardziej agresywny system korzeniowy w stosunku do roślin strączkowych, jednak uzyskując niższy plon nasion w stosunku do siewu czystego. Stres środowiskowy roślin w siewie mieszanym wpłynął na wzrost masy korzeni, czego efektem było obniżenie wskaźnika RSR. 